\title{
Kushenin combined with adefovir dipivoxil affects the HBV-DNA load in serum, immune functions and liver functions of patients with chronic hepatitis B
}

\author{
JING FENG, JIANDONG HUANG and ZHIQIN LI \\ Department of Infectious Diseases, Weifang People's Hospital, Weifang, Shandong 261041, P.R. China
}

Received June 2, 2017; Accepted September 22, 2017

DOI: $10.3892 / \mathrm{etm} .2017 .5266$

\begin{abstract}
This study aimed to explore the effect of kushenin combined with adefovir dipivoxil on the load of hepatitis B virus DNA (HBV-DNA) in serum, in immune functions and in liver functions of patients with chronic hepatitis B. A sample of 80 patients with chronic hepatitis B was selected who were admitted to Weifang People's Hospital for treatment between January, 2013 and December, 2015. They were divided into the observation group $(n=40)$ and the control group $(n=40)$. The patients in both groups received adefovir dipivoxil, while those in the observation group additionally received the kushenin. Variations in HBV-DNA load and transforming growth factor- $\beta 1$ (TGF- $\beta 1$ ) in the two groups were detected before intervention, at 1 month, 3 months and 6 months after intervention. In addition, after intervention, we also observed the changes in $\mathrm{CD}^{+}, \mathrm{CD}^{+}$and $\mathrm{CD} 4^{+} / \mathrm{CD}^{+}$, as well as the levels of immune globulin. Furthermore, in these two groups, we detected the changes in endotoxin in serum before and after intervention, the liver function after intervention, and the variations of hyaluronic acid (HA) and type III procollagen (PCIII) before and after intervention which were used to serve as the indicators for hepatic fibrosis. Results showed that at one month, 3 months and 6 months after intervention, HBV-DNA load and the level of TGF- $\beta 1$ in the observation group were lower than those in the control group $(\mathrm{P}<0.05)$. In the observation group, the HBV-DNA load at 6 months after intervention was the lowest, sequentially followed by the levels at 3 months, at 1 month and before intervention $(\mathrm{P}<0.05)$. After intervention, the levels of $\mathrm{CD}^{+}$and $\mathrm{CD} 8^{+}$and $\mathrm{CD} 4^{+} / \mathrm{CD} 8^{+}$in the observation group were higher than those in the control group $(\mathrm{P}<0.05)$. Moreover, the levels of immunoglobulin M $(\operatorname{IgM})$, immunoglobulin $\mathrm{G}(\mathrm{IgG})$ and immunoglobulin $\mathrm{A}(\operatorname{Ig} \mathrm{A})$ were
\end{abstract}

Correspondence to: Dr Zhiqin Li, Department of Infectious Diseases, Weifang People's Hospital, 151 Guangwen Street, Kuiwen, Weifang, Shandong 261041, P.R. China

E-mail: zhiqin_li1@163.com

Key words: kushenin, adefovir dipivoxil, chronic hepatitis B, hepatitis B virus-DNA load, transforming growth factor- $\beta 1$, immune function; liver function elevated in the observation group compared to the levels in the control group $(\mathrm{P}<0.05)$. Additionally, the level of endotoxin in serum, the levels of alanine aminotransferase (ALT), aspartate aminotransferase (AST) and total bilirubin (TBil). Besides, after intervention, the levels of HA and PCIII in the observation group were found to be lower than those in the control group before and after intervention $(\mathrm{P}<0.05)$. This study concludes that, for patients with chronic hepatitis $\mathrm{B}$, kushenin combined with adefovir dipivoxil can remarkably decrease the HBV-DNA load, improve their immunity, ameliorate the liver function and delay the onset of liver cirrhosis.

\section{Introduction}

Hepatitis B virus (HBV) is one of the most common DNA viruses at present which belongs to the Hepadnaviridae family of viruses. It is also considered as one of the most serious issues of social public health in China (1), where a larrge population of patients is with hepatitis B. Among these patients, according to the statistics, HBV carriers are one tenth of the population. The liver cirrhosis after the onset of hepatitis B is considered as one of the terminal-stage disease courses of patients with hepatitis B. With the progression in the disease course of hepatitis, many patients in middle- or terminalstages have been complicated with liver cirrhosis (2). Due to the features of liver cirrhosis after the onset of hepatitis B, such as the hidden onset, there is a long disease course and slow progression. People in general have paid less attention to hepatitis B which is the onset of liver cirrhosis; especially the type complicated with the formation of ascites and frequently leads to a rapid progression of disease, thereby affecting the life of patients. Thus, it generally serves as the sign indicating the transition of liver function of patients with hepatitis B from the compensated stage to the decompensated stage (3).

Currently, antivirus therapy has been the most common method for treatment of patients with hepatitis B. Comprehensive therapies including immunotherapy are also applied (4). Nevertheless, due to the special features of HBV, viruses are hard to disinfect thoroughly through clinical treatment. Thus, in evaluating the efficiency of treatment, variation in virus load of HBV-DNA serves as an indicator (5). Moreover, causing delay to the onset of liver cirrhosis after hepatitis B is regarded as the major target in clinical practice (6) and for this 
purpose, adefovir dipivoxil is one of the antivirus drugs that are commonly used. Kushenin, as the alkaloid compound of oxymatrine and minute oxysophocarpine, is often applied in the correction of decrease in leukocytes caused by treatment of chronic hepatitis B, radiotherapy and chemotherapy as well as the treatment of leukopenia caused by other factors (7). In this study, to further improve the efficacy of treatment on hepatitis B, we mainly adopted the combined treatment of Traditional Chinese Medicine (TCM) and Western medicine as the treatment method.

\section{Materials and methods}

General materials. A total of 80 patients with chronic hepatitis B was selected who were admitted to Weifang People's Hospital for the treatment between January, 2013 and December, 2015. All patients underwent biochemistry examinations, and based on the results and on the medical history, we excluded the patients who were complicated with severe cardiorespiratory disorders, or had received therapies with the administration of immune preparations within one year before this study, or were allergic to the drugs used in this study, or were complicated with mental diseases. Furthermore, written signed informed consent was obtained from the patients, and this study was approved by the Ethics Committee of Weifang People's Hospital. Patients were divided into the observation group $(n=40)$ and the control group $(n=40)$ at random. The observation group consisted of 29 males and 11 females aged from 39 to 70 years (average age of $49.6 \pm 2.3$ years). In addition, the disease course of hepatitis B was between 5 and 45 years with an average of $23.3 \pm 1.1$ years. Furthermore, 13 patients were positive to hepatitis B surface antigen (HBsAg), hepatitis $\mathrm{B}$ virus e-antigen ( $\mathrm{HBeAg}$ ) and hepatitis B core antibody $(\mathrm{HBcAb})$, and 27 patients were positive to $\mathrm{HBs} A G$, hepatitis $\mathrm{B}$ virus e-antibody $(\mathrm{HBe} A b)$ and $\mathrm{HBcAb}$. There were 21 patients with alcohol-drinking history. The control group consisted of 30 males and 10 females aged from 40 to 70 years (average age of $49.5 \pm 2.4$ years). The disease course of hepatitis B was between 5 and 45 years with an average of 23.5 \pm 1.0 years. Moreover, 12 patients were positive to $\mathrm{HBsAg}, \mathrm{HBeAg}$ and $\mathrm{HBcAb}$, and 28 patients were positive to $\mathrm{HBs} A \mathrm{G}, \mathrm{HBeAb}$ and $\mathrm{HBcAb}$. In this group, 20 patients had alcohol-drinking history. Comparison of gender, age, disease course and type of hepatitis B, and the alcohol-drinking history showed no statistically significant differences $(\mathrm{P}>0.05)$ between the two groups.

Treatment methods. During the treatment, the progression in the disease course of patients was observed closely, and proper treatment method and support were provided for dealing with the specific symptoms. Regular examinations were carried out to detect the changes in the blood routine parameters, coagulation function, hepatic function and renal functions. Once patients were found with the levels of ALT and/or AST over 200 U/1, live-protective drugs were given immediately. The patients were withdrawn from administration of interferon and immunosuppressive agent as soon as they were enrolled into the study. In the control group, an oral administration of adefovir dipivoxil (q.d., 10 mg/day; NMPN: H20060666; Chia Tai Tianqing Pharmaceutical Group Co., Ltd., Jiangsu,
China) was performed for fasting patients in the morning, where one course of treatment referred to the consecutive administration for 48 weeks. In the observation group, patients were given kushenin (t.i.d., 0.2 g/time; NMPN: 403405H28; Chia Tai Tianqing Pharmaceutical Group Co., Ltd.) in addition to the adefovir dipivoxil. Here one cycle of treatment consisted of two consecutive courses of treatment that was constituted by 24 consecutive weeks of treatment.

Observation indexes. Variations in HBV-DNA load and transforming growth factor- $\beta 1$ (TGF- $\beta 1$ ) in the two groups were detected before intervention, at 1 month, 3 months and 6 months after intervention. In addition, after intervention, we also observed the changes in $\mathrm{CD}^{+}, \mathrm{CD}^{+}$and $\mathrm{CD} 4^{+} / \mathrm{CD}^{+}$, as well as the levels of immune globulin. Furthermore, in both groups, we detected the changes in endotoxin in serum before and after intervention, the liver function after intervention, and the variations of hyaluronic acid (HA) and type III procollagen (PCIII) which served as the indicators for hepatic fibrosis before and after intervention.

Assessment methods. The assay of HBV-DNA load was performed through fluorescence quantification polymerase chain reaction $(\mathrm{PCR})$, in which the normal range was not $>500 \mathrm{copy} / \mathrm{ml}$, TGF- $\beta 1$ level was detected via enzymelinked immunosorbent assay (ELISA), the levels of endotoxin in serum was measured via limulus ameobatic chromogenic assay (normal reference value was set at $0.1 \mathrm{EU} / \mathrm{ml}$ ). Relative indexes of liver functions including the levels of alanine aminotransferase (ALT), aspartate aminotransferase (AST) and total bilirubin (TBil) were all measured using the Olympus AU2700 Automatic Biochemical Analyzer, in which the normal reference range in adults of TBil was between 3.4 and $20 \mu \mathrm{mol} / 1$ while the normal reference values of ALT and AST in adults were below $40 \mathrm{U} / 1$. For cellular immune functions, the cell count of $\mathrm{T}$ lymphocyte subgroups, $\mathrm{CD} 4^{+}$ and $\mathrm{CD}^{+}$, was performed using the BD FRCS Calibur Flow Cytometer (BD Biosciences, Franklin Lakes, NJ, USA) automatically during which the supplementary reagents produced by $\mathrm{BD}$ were used, and $5 \mathrm{ml}$ fasting elbow venous blood samples were collected in the morning and treated using ethylenediaminetetraacetic acid (EDTA) for later preservation. All the samples were delivered for examination within $12 \mathrm{~h}$ after removal from the body. For humoral immune functions, ELISA was performed for assay of immunoglobulin $\mathrm{M}(\operatorname{IgM})$, immunoglobulin $\mathrm{G}(\mathrm{IgG})$ and immunoglobulin $\mathrm{A}(\operatorname{Ig} \mathrm{A})$ in the body, in which the normal range of $\mathrm{IgG}$ in adults was set between 9.6 and $23.6 \mathrm{mg} / \mathrm{l}$, the normal range of $\mathrm{IgM}$ was between 3.05 and $3.85 \mathrm{mg} / \mathrm{l}$, and the normal range of $\mathrm{IgA}$ was between 3.14 and $4.66 \mathrm{mg} / \mathrm{l}$. The levels of HA and PCIII were measured through solid-phase radioimmunoassay, in which the normal reference value of HA in adults was set as $47.6 \pm 22.5 \mathrm{ng} / \mathrm{ml}$ and the normal range of PCIII in adults was below $120 \mu \mathrm{g} / 1$.

Statistical analysis. SPSS 13.0 provided by IBM (Chicago, IL, USA) was used to perform statistical analysis. The measurement data was presented as mean \pm standard deviation. The comparison of means between the two groups was carried out using t-tests. In addition, the Chi-square test was performed for intergroup comparison of rates. Furthermore, intragroup 
Table I. Comparison of HBV-DNA load at different time-points before and after intervention between the two groups (copy/ml).

\begin{tabular}{lccccc}
\hline Group & $\begin{array}{c}\text { Before } \\
\text { intervention }\end{array}$ & $\begin{array}{c}\text { In 1 month } \\
\text { after intervention }\end{array}$ & $\begin{array}{c}\text { In 3 months } \\
\text { after intervention }\end{array}$ & $\begin{array}{c}\text { In 6 months } \\
\text { after intervention }\end{array}$ & $\begin{array}{c}\text { F-value } \\
\text { P-value }\end{array}$ \\
\hline Observation group & $16311.2 \pm 103.6$ & $11326.2 \pm 89.9$ & $327.2 \pm 32.8$ & $213.5 \pm 21.5$ & 191.092 \\
Control group & $16315.3 \pm 104.3$ & $12312.5 \pm 99.1$ & $829.1 \pm 41.2$ & $505.3 \pm 89.3$ & 114.192 \\
t-value & 0.163 & 46.621 & 24.248 & 6.321 & $<0.01$ \\
P-value & 0.871 & $<0.01$ & $<0.01$ & $<0.01$ & - \\
\hline
\end{tabular}

HBV-DNA, hepatitis B virus DNA.

Table II. Comparison of TGF- $\beta 1$ level at different time-points before and after intervention between the two groups (pg/ml).

\begin{tabular}{|c|c|c|c|c|c|c|}
\hline Group & $\begin{array}{c}\text { Before } \\
\text { intervention }\end{array}$ & $\begin{array}{l}\text { In } 1 \text { month } \\
\text { after intervention }\end{array}$ & $\begin{array}{l}\text { In } 3 \text { months } \\
\text { after intervention }\end{array}$ & $\begin{array}{l}\text { In } 6 \text { months } \\
\text { after intervention }\end{array}$ & F-value & P-value \\
\hline Observation group & $128.6 \pm 21.0$ & $100.2 \pm 18.1$ & $81.2 \pm 12.4$ & $63.3 \pm 8.9$ & 11.292 & $<0.01$ \\
\hline Control group & $130.1 \pm 20.9$ & $115.4 \pm 19.2$ & $92.1 \pm 14.2$ & $99.6 \pm 13.8$ & 9.192 & $<0.01$ \\
\hline t-value & 0.320 & 3.643 & 3.657 & 13.981 & - & - \\
\hline $\mathrm{P}$-value & 0.750 & $<0.01$ & $<0.01$ & $<0.01$ & - & - \\
\hline
\end{tabular}

TGF- $\beta 1$, transforming growth factor- $\beta 1$.

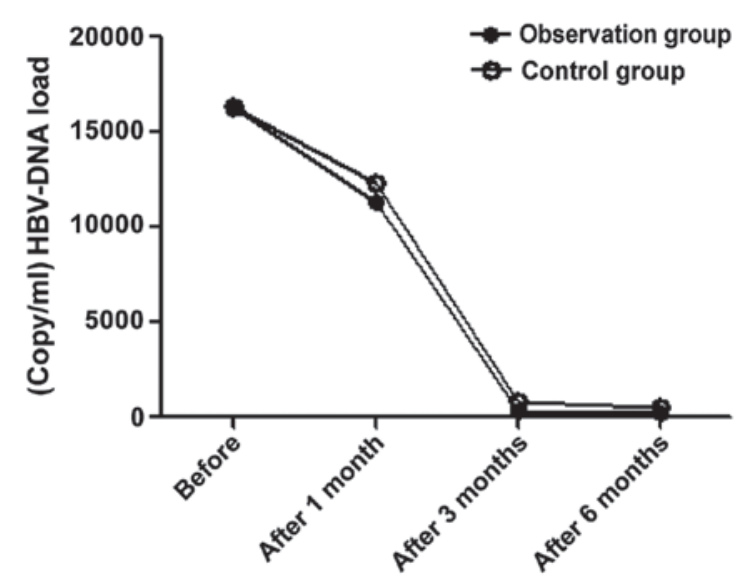

Figure 1. Comparison of hepatitis B virus DNA (HBV-DNA) load at different time-points between two groups before and after intervention.

comparisons at different time-points before and after intervention were made using the variance analysis of repeated measurements. For all statistical test, $\mathrm{P}<0.05$ was considered as the statistical significance level.

\section{Results}

Comparison of HBV-DNA load at different time-points before and after intervention between the two groups. Results showed (Table I), that there was no statistical significant difference between groups in terms of HBV-DNA load $(\mathrm{P}>0.05)$ before intervention. However, at 1, 3 and 6 months after intervention, we found that the HBV-DNA loads in the observation group were lower than those in the control group in the same period $(\mathrm{P}<0.05)$. Moreover, in the observation

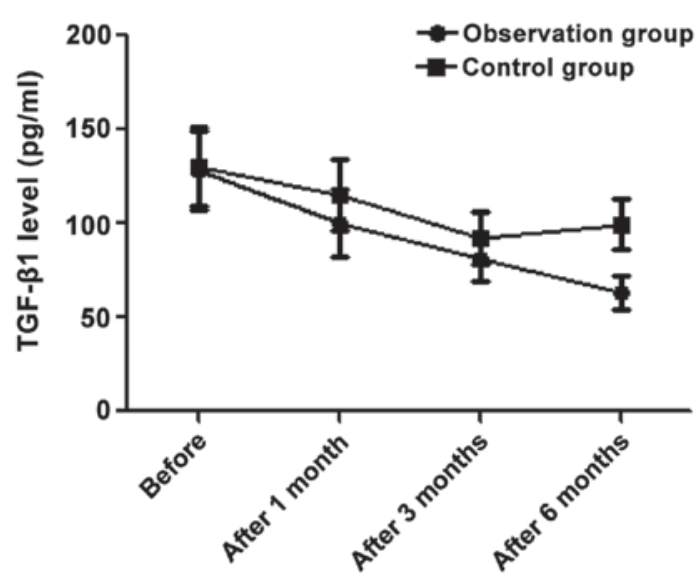

Figure 2. Comparison of transforming growth factor- $\beta 1$ (TGF- $\beta 1$ ) levels at different time-points between two groups before and after intervention.

group, the HBV-DNA load at 6 months after intervention was the lowest, followed by the levels at 3 months, at 1 month and before intervention $(\mathrm{P}<0.05)$ (Fig. 1).

Comparison of TGF- $\beta 1$ level at different time-points before and after intervention between the two groups. The results showed (Table II), that there was no statistically significant difference in comparison of TGF- $\beta 1$ level between the two groups $(\mathrm{P}>0.05)$ before intervention. However, at 1, 3 and 6 months after intervention, we found that the TGF- $\beta 1$ levels in the observation group were all lower than those in the control group in the same period $(\mathrm{P}<0.05)$. In the observation group, the TGF- $\beta 1$ level at 6 months after intervention was the lowest, and sequentially followed by the levels at 3 months, at 1 month and before intervention $(\mathrm{P}<0.05)$ (Fig. 2). 
Table III. Comparison of the variations in $\mathrm{CD}^{+}, \mathrm{CD}^{+}$and $\mathrm{CD}^{+} / \mathrm{CD}^{+}$levels after intervention between the two groups.

\begin{tabular}{lccc}
\hline Group & $\mathrm{CD}^{+}\left(\mathrm{mm}^{3}\right)$ & $\mathrm{CD}^{+}\left(\mathrm{mm}^{3}\right)$ & $\mathrm{CD}^{+} / \mathrm{CD}^{+}$ \\
\hline Observation group & $35.1 \pm 2.0$ & $30.6 \pm 1.3$ & $1.9 \pm 0.3$ \\
Control group & $26.0 \pm 0.9$ & $24.4 \pm 1.0$ & $1.6 \pm 0.2$ \\
t-value & 26.242 & 23.908 & 5.262 \\
P-value & $<0.01$ & $<0.01$ & $<0.01$ \\
\hline
\end{tabular}

Table IV. Comparison of the variations in immunoglobulin after intervention between the two groups ( $\mathrm{mg} / \mathrm{l})$.

\begin{tabular}{lccc}
\hline Group & $\operatorname{IgM}$ & $\operatorname{IgG}$ & $\operatorname{IgA}$ \\
\hline Observation group & $1.6 \pm 0.03$ & $9.5 \pm 0.12$ & $3.9 \pm 0.20$ \\
Control group & $1.3 \pm 0.02$ & $8.8 \pm 0.10$ & $1.8 \pm 0.15$ \\
t-value & 52.623 & 28.342 & 53.126 \\
P-value & $<0.01$ & $<0.01$ & $<0.01$ \\
\hline
\end{tabular}

IgM, immunoglobulin M; IgG, immunoglobulin G; IgA, immunoglobulin A.

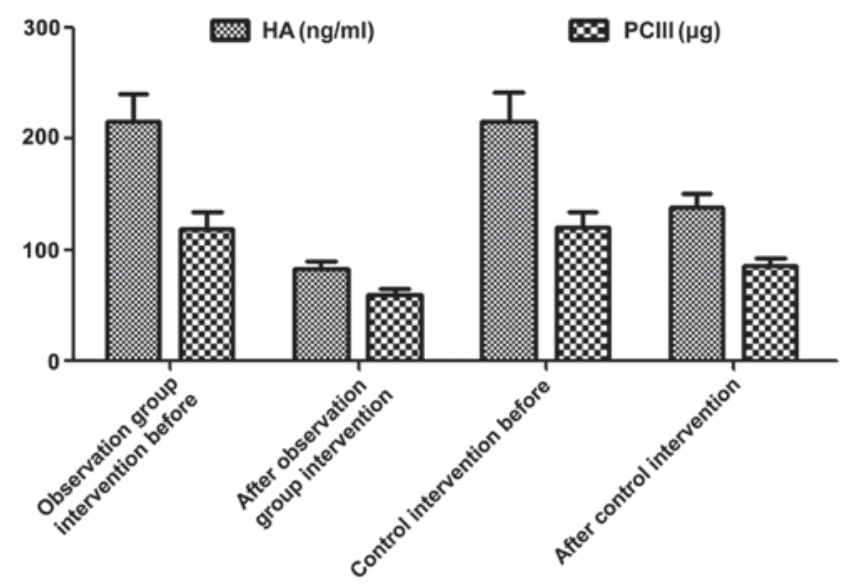

Figure 3. Comparison of the indicators of hepatic fibrosis [hyaluronic acid (HA) and type III procollagen (PCIII)] between the two groups before and after intervention.

Comparison of the variations in $\mathrm{CD}^{+}, \mathrm{CD}^{+}$and $\mathrm{CD4^{+ }} / \mathrm{CD} 8^{+}$ levels after intervention between the two groups. After intervention, the levels of $\mathrm{CD}^{+}$and $\mathrm{CD}^{+}$in the observation group were higher compared to those of the control group $(\mathrm{P}<0.05)$, while on the other hand, $\mathrm{CD}^{+} / \mathrm{CD}^{+}$was higher than that in the control group $(\mathrm{P}<0.05)$ (Table III).

Comparison of the variations in immunoglobulin after intervention between the two groups. The results (Table IV), showed that after intervention, the levels of $\operatorname{IgM}, \operatorname{IgG}$ and $\operatorname{IgA}$ in the observation group were significantly higher than those in the control group $(\mathrm{P}<0.05)$.

Comparison of level of endotoxin in serum between the two groups before and after intervention. Before intervention, no
Table V. Comparison of level of endotoxin in serum between the two groups before and after intervention (EU/ml).

\begin{tabular}{lcc}
\hline Group & Before treatment & After treatment \\
\hline Observation group & $1.31 \pm 0.3$ & $0.06 \pm 0.01$ \\
Control group & $1.30 \pm 0.3$ & $0.99 \pm 0.06$ \\
t-value & 0.149 & 96.967 \\
P-value & 0.882 & $<0.01$ \\
\hline
\end{tabular}

Table VI. Comparison of the indexes related to liver functions after intervention between the two groups (mean $\pm \mathrm{SD}$ ).

\begin{tabular}{lccc}
\hline Group & ALT (U/l) & AST (U/l) & TBil $(\mu \mathrm{mol} / \mathrm{l})$ \\
\hline Observation group & $37.6 \pm 2.5$ & $39.5 \pm 2.4$ & $19.5 \pm 2.8$ \\
Control group & $60.6 \pm 5.9$ & $59.8 \pm 6.3$ & $29.8 \pm 4.6$ \\
t-value & 22.701 & 19.044 & 12.097 \\
P-value & $<0.01$ & $<0.01$ & $<0.01$ \\
\hline
\end{tabular}

ALT, alanine aminotransferase; AST, aspartate aminotransferase; TBil, total bilirubin.

statistically significant difference was found in comparison of endotoxin level in serum between the two groups ( $\mathrm{P}>0.05)$. However, after intervention, the level of endotoxin in serum in the observation group was significantly lower than that in the control group $(\mathrm{P}<0.05)$ (Table $\mathrm{V})$.

Comparison of the indexes related to liver functions after intervention between the two groups. The results show (Table VI), that after treatment, the levels of ALT, AST and TBil in the observation group were significantly lower than those in the control group.

Comparison of the indicators of hepatic fibrosis (HA and PCIII) between the two groups before and after intervention. Before intervention, the level of HA in the observation group was $215.6 \pm 25.3 \mathrm{ng} / \mathrm{ml}$, and the level of PCIII was $119.5 \pm 14.3 \mu \mathrm{g} / \mathrm{l}$. After intervention, the HA level was $83.2 \pm 7.1 \mathrm{ng} / \mathrm{ml}$, and the PCIII level was $60.3 \pm 5.1 \mu \mathrm{g} / \mathrm{l}$. In addition, before intervention, the level of HA in the control group was $216.3 \pm 25.6 \mathrm{ng} / \mathrm{ml}$, and the level of PCIII was $120.1 \pm 14.5 \mu \mathrm{g} / 1$. After intervention, the HA level was $138.6 \pm 11.9 \mathrm{ng} / \mathrm{ml}$, and the PCIII level was $86.6 \pm 6.8 \mu \mathrm{g} / 1$. Furthermore, before intervention, there was no statistically significant difference in HA and PCIII between the two groups $(\mathrm{P}>0.05)$. However, after the intervention, the levels of HA and PCIII in the observation group were lower than those in the control group before and after intervention $(\mathrm{P}<0.05)$ (Fig. 3).

\section{Discussion}

Hepatitis B is an important factor that often causes hepatic cirrhosis. The onset of hepatic cirrhosis is usually accompanied by the decrease in urine volume (8) as well as the 
disorders in circulatory function (9) and coagulation function. Among the patients with hepatic cirrhosis, the mortality rate in those who have not received any timely treatment is $>40 \%$ (10). In Traditional Chinese Medicine, hepatic cirrhosis after hepatitis B is also included in the range of 'dilation' and 'coagulation' (11), and it is believed that it is caused by deficiency in origin and excess in superficiality, which are intermingled with the disorder of liver and spleen. These lead to the stagnation of $q i$ in liver and dysfunction of spleen in transport, and further contribute to the blockage in transport of moisture and accumulation of moisture and turbidity (12). In addition, the accumulated moisture affects the activities of $q i$, and thus cause imbalance in the transport controlled by spleen, deficiency of yang-qi and significant increase in turbid yin. Furthermore, the gradually accumulated moisture in the body is quite difficult to be excreted, plus the siltation of qi, blood, water and hypochondrium mass in the abdomen, resulting in the sclerosis in hepatic lobule. Currently, strengthening the resistance to eliminate the pathogenic factors and the treatment of liver and spleen together have been considered as the preferable choice in practice of TCM.

As a new type of nucleotide reverse transcriptase inhibitor, namely the adefovir dipivoxil, was used in this study which can effectively antagonize a variety of viruses. It has been recommended by World Health Organization as the first-line drug for treatment of infections of hepatitis B and acquired immune deficiency syndrome. The efficacy on these diseases has been observed in clinical practice (13). However, for treatment of hepatitis B, patients who take adefovir dipivoxil can hardly persist due to the long-term administration and serious adverse reactions (14). Thereupon, in addition to adefovir dipivoxil, patients in this study also took kushenin. Kushenin is a kind of alkaloid with biological activity extracted from the sophora alopecuroide and yellowish sophora root, and the effective constituent is oxymatrine (15). After 1, 3 and 6 months of intervention, we found that the HBV-DNA load and the level of TGF- $\beta 1$ in the observation group were lower than those that only took adefovir dipivoxil in the control group during the same period. In the observation group, the HBV-DNA load at 6 months after intervention was the lowest, and sequentially followed by the levels at 3 months, at 1 month and before intervention. These finding suggested that kushenin combined with the adefovir dipivoxil can effectively decrease the HBV-DNA load and the TGF- $\beta 1$ level in the treatment of chronic hepatitis B. In addition, comparisons of the cellular and humoral immune functions during the treatment in both groups showed that after intervention, the levels of $\mathrm{CD}^{+}, \mathrm{CD}^{+}$and $\mathrm{CD}^{+} / \mathrm{CD}^{+}$in the observation group were higher than those in the control group. Moreover, after intervention, the levels of $\operatorname{IgM}, \operatorname{IgG}$ and $\operatorname{IgA}$ were elevated in the observation group compared to levels in the control group suggesting that for the treatment of hepatitis B, kushenin combined with adefovir dipivoxil can remarkably improve the immune functions of patients. At the same time, we also compared the levels of endotoxin in serum between the two groups before and after intervention. The results showed that the level of endotoxin in serum in the patients of the observation group indicate that kushenin combined with adefovir dipivoxil can alleviate the toxicity generated by endotoxin in serum, thereby improve the prognosis of patients. Finally, we detected the changes in liver function after treatment and the associated indicators of hepatic fibrosis (HA and PCIII). The results also showed that after intervention, the level of endotoxin in serum in patients of the observation group was significantly lower than that in the control group. Simultaneously, we found that after intervention, the levels of HA and PCIII in the observation group were lower than those in the control group before intervention. This reveals that kushenin combined with adefovir dipivoxil is of great importance for improving the hepatic function and delaying the progression of liver cirrhosis in treatment of hepatitis B.

After the patients in the observation group received the combination treatment of kushenin and adefovir dipivoxil, the HBV-DNA load and TGF- $\beta 1$ levels were significantly decreased, and the immune function was effectively improved, which may be correlated with the features of oxymatrine, the effective constituent of kushenin, such as the anti-inflammation effect and the capability to eliminate the free radicals (16), regulate the immune functions of human, stabilize the structure of membrane and induce the activation of enzymatic activity of liver-specific drugs (17). Combination medication of kushenin and adefovir dipivoxil can remarkably improve the immune functions of patients, and also facilitate the substantial generation of anti-HBV antibodies by B cells (18), thereby ameliorating the liver function, reducing the level of aminotransferase (19) and the HBV-DNA load, and increasing the negative-conversion rate of $\mathrm{HBeAg}$. Besides, kushenin can also effectively inhibit cell apoptosis in liver and the proliferation of fibroblasts, and suppress the expressions of TGF- $\beta 1$, HA and PCIII to delay the onset of hepatic fibrosis (20).

This study concluded that for patients with chronic hepatitis B, kushenin combined with adefovir dipivoxil can significantly decrease the HBV-DNA load, ameliorate the immune function and liver function, and delay the onset of hepatic cirrhosis.

\section{References}

1. Sun YH, Zhang XY, Xie WQ, Liu GJ, He XX, Huang YL, Zhang GX, Wang J, Kuang ZY and Zhang R: Identification of UQCRB as an oxymatrine recognizing protein using a T7 phage display screen. J Ethnopharmacol 193: 133-139, 2016.

2. Zhang YB, Zhan LQ, Li GQ, Wang F, Wang Y, Li YL, Ye WC and Wang GC: Dimeric matrine-type alkaloids from the roots of Sophora flavescens and their anti-hepatitis B virus activities. J Org Chem 81: 6273-6280, 2016.

3. Chen JX, Shen HH, Niu M, Guo YM, Liu XQ, Han YZ, Zhang YM, Zhao YL, Bai BK, Zhou WJ, et al: Anti-hepatitis B virus effect of matrine-type alkaloid and involvement of p38 mitogen-activated protein kinase and tumor necrosis factor receptor-associated factor 6. Virus Res 215: 104-113, 2016.

4. Kan QC, Zhang S, Xu YM, Zhang GX and Zhu L: Matrine regulates glutamate-related excitotoxic factors in experimental autoimmune encephalomyelitis. Neurosci Lett 560: 92-97, 2014.

5. Ma ZJ, Li Q, Wang JB, Zhao YL, Zhong YW, Bai YF, Wang RL, Li JY, Yang HY, Zeng LN, et al: Combining oxymatrine or matrine with lamivudine increased its antireplication effect against the hepatitis B virus in vitro. Evid Based Complement Alternat Med 2013: 186573, 2013.

6. Chen CX, Liu B, Hu Y, Johnson JE and Tang YW: Subacute fulminant hepatic failure with intermittent fever. Hepatobiliary Pancreat Dis Int 8: 657-659, 2019, 2009.

7. Chen CX, Liu B, Ma Y, Zhou YJ, Pan XN, Zhen RD, Wang QC, Wang MR, He CL, Fu QC, et al: Lamivudine, interferon-alpha and oxymatrine treatment for the surviving hepatic failure patients with hepatitis B. Zhonghua Gan Zang Bing Za Zhi 17: 505-508, 2009 (In Chinese). 
8. Ye G, Zhu HY, Li ZX, Ma CH, Fan MS, Sun ZL and Huang CG: LC-MS characterization of efficacy substances in serum of experimental animals treated with Sophora flavescens extracts. Biomed Chromatogr 21: 655-660, 2007.

9. Lin Y, Pan F, Wang Y, Chen Z, Lin C, Yao L, Zhang X, Zhou R and Pan C: Adefovir dipivoxil-induced Fanconi syndrome and its predictive factors: A study of 28 cases. Oncol Lett 13: 307-314, 2017.

10. Gao YH, Meng QH, Zhang ZQ, Zhao P, Shang QH, Yuan Q, Li Y, Deng J, Li T, Liu XE, et al: On-treatment quantitative hepatitis B e antigen predicted response to nucleos(t)ide analogues in chronic hepatitis B. World J Hepatol 8: 1511-1520, 2016.

11. Luo Q, Deng Y, Cheng F, Kang J, Zhong S, Zhang D and Zeng W: Relationship between nephrotoxicity and long-term adefovi dipivoxil therapy for chronic hepatitis B: A meta-analysis. Medicine (Baltimore) 95: e5578, 2016.

12. Shen X, Fu B, Liu Y, Guo C, Ye Y, Sun R, Li J, Tian Z and Wei H: $\mathrm{NKp} 30(+) \mathrm{NK}$ cells are associated with HBV control during pegylated-interferon-alpha-2b therapy of chronic hepatitis B. Sci Rep 6: 38778, 2016

13. Wang LP, Han FZ, Yan XB, Fan YC and Wang K: Relationship between hepatitis $\mathrm{B}$ virus reverse transcriptase 181 mutation and $\mathrm{S}$ gene mutation in hepatitis $\mathrm{B}$ virus chronically infected patients. Cell Mol Biol (Noisy-le-grand) 62: 18-23, 2016.

14. Zhong JH, Ke Y, Zhu SL, Wang L, Luo CP, Gong WF, You XM, Ma L, Xiang BD and Li LQ: Adefovir dipivoxil is less expensive than lamivudine and associated with similar prognosis in patients with hepatitis B virus-related hepatocellular carcinoma after radical resection. Onco Targets Ther 9: 6897-6907, 2016.
15. Li Z, Shen C, Wang Y, Wang W, Zhao Q, Liu Z, Wang Y and Zhao C: Circulating kidney injury molecule-1 is a novel diagnostic biomarker for renal dysfunction during long-term adefovir therapy in chronic hepatitis B. Medicine (Baltimore) 95: e5264, 2016.

16. Hara Y, Tokodai K, Nakanishi C, Miyagi S and Kawagishi N: Spontaneous resolution of de novo hepatitis B after living donor liver transplantation with hepatitis B core antibody positive graft: A case report. Surg Case Rep 2: 118, 2016.

17. Banerjee S, Gunda P, Drake RF and Hamed K: Telbivudine for the treatment of chronic hepatitis B in HBeAg-positive patients in China: A health economic analysis. Springerplus 5: 1719, 2016.

18. Tacke F and Kroy DC: Treatment for hepatitis B in patients with drug resistance. Ann Transl Med 4: 334, 2016.

19. Cai Q, Chen K, Chen J, Wu S, Geng Q, Huang H, Lin T, Jiang W, Xia Z, Duan H, et al: The effect of prophylactic lamivudine plus adefovir therapy compared with lamivudine alone in preventing hepatitis $\mathrm{B}$ reactivation in lymphoma patients with high baseline HBV DNA during chemotherapy. PLoS One 11: e0164210, 2016.

20. Kawamura Y, Kobayashi M, Saitoh S, Arase Y, Ikeda K, Kobayashi M, Mineta R, Suzuki Y, Suzuki F, Suzuki Y, et al: Efficacy of long-term tenofovir-based rescue therapy in patients with chronic hepatitis B refractory to nucleoside/nucleotide analogs. J Gastroenterol 11: 132-136, 2016. 